\title{
NO KONFLIKTA UZ KOPĪBU - CIKTĀL IESPĒJAMA KOPĪGA BAZNĪCAS SVINĒŠANA?
}

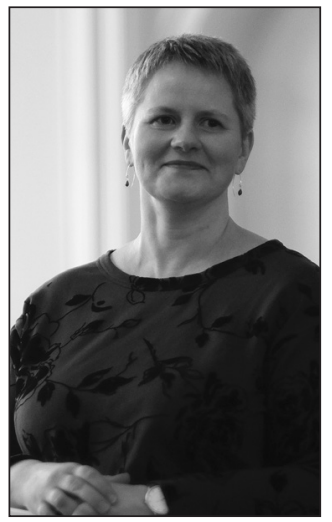

Dace Balode kopš 2000. gada strādā LU Teologiijas fakultātē, pašlaik ir šīs fakultātes dekāne un profesore Bībeles teolog̣ijā. Teoloǵiju viņa ir studējusi LU, kā arī Bāzeles un Bernes Teologijas fakultātē, sadarbojoties ar Šveices Jaunās Derības pētnieku profesoru Ulrihu Lucu (Ulrich Luz). Doktora diplomu ieguvusi Tartu Universitātes Teologiijas fakultātē. Akadēmiskās intereses saistās ar biblisko teologiju un tekstu interpretācijas teorijām un vēsturi, kā arī sievietes lomu kristīgajā tradīcijā. Šajās jomās viṇa publicējusi savus pētniecības darbus, tostarp monogrāfiju Gottesdienst in Korinth (Dievkalpojums Korintā, 2011), kas veltīta kristīgā dievkalpojuma pirmsākumiem. Viņa ir Eiropas sieviešu teologu apvienības valdes locekle. 2018. gadā ordinēta Latvijas Evanggēeliski luteriskajā baznīcā ārpus Latvijas.
Raksturvārdi: ekumene, ekumeniskais dialogs, katoḷu-luterāṇu dialogs.

2017. gadā tika atzīmēta reformācijas piecsimtgade. Neapšaubāmi, tām baznīcām, un īpaši evanggéliski luteriskajai baznīcai, kas atsaucas uz Mārtina Lutera teologíiju, tas bija liels notikums. Tomēr jājautā, vai šis notikums ir nozīmīgs arī plašākā ekumeniskā skatījumā? Vai baznīcas var vienoties šīs norises svinībās? Vai evaṇgéliski luteriskā un Romas Katoḷu baznīca, kas taču, pateicoties tieši reformācijas procesiem, ir gadsimtus gājušas dažādus ceḷus, var kopā atzīmēt reformācijas gadadienu? 2017. gads rādīja, ka tomēr ir pietiekami daudz kopīga luterāṇu un katoḷu starpā, ka kopīgas svinības patiešām arī norisinājās, no kurām visievērojamākās bija Lundā 31. oktobrī. Tajās piedalījās Pasaules Luterāņu federācijas prezidents bīskaps Munibs Junāns un pāvests Francisks. Šo luteriskās reformācijas gadadienu gaidot, luterānu un katoḷu teologi izstrādāja kopīgu dokumentu No konflikta un vienotību.
Ekumeniskā kustība ir kḷuvusi īpaši nozīmīga 20. gadsimtā, pēc šḳelšanās gadu tūkstoša tas nu jau iegājis vēsturē kā "ekumeniskais gadsimts". ${ }^{1}$ Jau pēc Halcedonas koncila 451. gadā atdalījās kristieši, kuri tagad veido senās Austrumu baznīcas (piem., koptu, armēnuu u. c.), nākamā lielā shizma starp Rietumu un Austrumu kristiešiem notika 1054. gadā ar abpusēju ekskomunikāciju. 1521. gada 3. janvārī ar bullu Decet Romanum Pontificem M. Luters tika izslēgts no baznīcas, tādējādi noslēdzot ārējo saišu saraušanu starp maǵistrātu un reformatoru. Reformācija 16. gs. veicināja baznīcas pluralizēšanos un sadalīšanos dažādās konfesijās un denomenācijās. Ilgus gadsimtus uzkrātā škiiršanās pieredze noteica attiecības baznīcu starpā, un arī vēl pašlaik ekumeniskais dialogs nebūt neaptver visas baznīcas visos līmen,os. Tomēr 20. gs. ieguvums ir vismaz tas, ka kristietības sadalītība vairs nav pieņemama kā pašsaprotama. ${ }^{2}$

\footnotetext{
1 Meyer 2015.

2 Turpat.
} 
Jau pirms Pirmā pasaules kara sākās baznīcu dialogi, to tālāko norisi apgrūtināja pasaules kari, kuros tika ierautas pasaules valstis, tomēr arī šo humāno katastrofu laikā baznīcas sadarbojās savā starpā, piem., palīdzot bēgliiem. 1948. gadā 23. augustā tika nodibināta Pasaules Baznīcu padome, kurā iesaistījās 351 delegāts no 147 baznīcām, 1968. gadā tai pievienojās arī Krievu pareizticīgā baznīca. Uz šīs panāktās bāzes dialogs var norisināties tālāk dažādos līmeṇos. Vienotības mērkis var nebūt strukturāla vienība un pat ne vienoti uzskati, tomēr ir būtiski apzināties, ka dažādās baznīcas ir pilnvērtīgas un līdztiesīgas viena Dieva kalpones. ${ }^{3}$ Vācu teologs Ulrihs Kertners (Ulrich Körtner) šajā zin̄ā runā par diferences jeb atškirību ekumeni (Differenzökumene). Ar to tiek uzsvērts, ka ekumeniskā dialoga ceḷā notiek satuvināšanās gan prakses, gan uzskatu ziṇā, tomēr var parādīties atškirīības, kas ir nesavienojamas dažādu baznīcu teologiskajās nostādnēs. Tur ekumenei ir jābūt pietiekami godīgai un jāiztur šīs atšķirības, un jāatzīst, ka kādos jautājumos konsenss nav panākams. Vēl vairāk ir paredzams, ka atškirīibas turpināsies vai pat radīsies no jauna. Tādā gadījumā ekumenes pamats būtu tas, ka baznīcas viena otru pilnībā atzīst kā baznīcas saskaņā ar ticības apliecību. ${ }^{4}$

Neapšaubāmi viens no pagrieziena punktiem 20. gs. ekumeniskā dialoga vēsturē bija Vatikāna II koncils, kurā atvērtība citām baznīcām bija nozīmīgs temats un kura dekrēts Unitatis redintegratio (Vienotības atjaunošana) 1964. gadā $\overline{5}^{5}$ parādīja lielāku atvērtību tālākai Romas Katoḷu baznīcas dalībai ekumeniskajā dialogā gan ar Austrumu, gan Rietumu baznīcām, t. sk. protestantu baznīcām. Starp Romas Katoḷu un luteriskajām baznīcām 20. gs. gaitā ir pieņemti vairāki nozīmīgi dokumenti. Šie dokumenti veidojušies bilaterālu sarunu rezultātā. Kopš 1967. gada tās uztur Luterāṇu un Romas katoḷu vienotības komisija, kurā darbojas teologi Pasaules Luterāṇu federācijas un Pontifikālās Kristiešu

\footnotetext{
3 Meyer 2015.

4 Körtner 2007.

5 Dekret 1964.
}

vienotības veicināšanas padomes uzdevumā. ${ }^{6}$ Viens no pašiem nozīmīgākajiem dokumentiem neapšaubāmi ir 1999. gadā pieņemtā Vienotā deklarācija par taisnošanas mācību, ko parakstīja abu baznīcu pārstāvji un kas atklāj, ka abas baznīcas pašos pamatos ir vienotas par taisnošanas mācības izpratni. Tas, protams, nenozīmē, ka to starpā arī šajā jautājumā nav atškirīibu, taču šì dokumenta nozīme ir tā, ka tas parāda abu baznīcu ekumenisko gribu un vēlmi atšḳetināt domstarpības, kas veidojušās atškirīgu jēdzienu lietojuma rezultātā. ${ }^{7}$

Visbeidzot, 2013. gadā lasītājiem tika nodots Luterāṇu un Romas katoḷu vienotības komisijas ziņojums No konflikta uz kopību. Tas, sagatavojot kopīgu reformācijas gadadienas atceri 2017. gadā, pievēršas dažādiem reformācijas radītiem jautājumiem abu baznīcu starpā. Dokumentā uzsvērts, ka 2017. gadā ekumenisma laikmetā vairs nav iespējams svinēt reformācijas gadadienu, neņemot vērā ekumenes perspektīvu uz tās vēsturi. Nav vairs iespējams tikai no vienas konfesijas ietvariem raudzīties uz reformācijas panākumiem vai zaudējumiem, pretnostādot dažādus konfesionālo grupu viedokḷus, kā tas bija noticis iepriekšêjās reformācijas svinībās. Dokuments tās vērtē kritiski: "Luterāṇiem š̄is atceres dienas un simtgades svinības deva iespēju vēlreiz pastāstīt par sev raksturīgās - "evaṇgèliskās" baznīcas sākumiem, lai pamatotu tās pastāvēšanu izteikti atškirīgā formā. Šis stāsts dabiski tika sasaistîts ar Romas katoḷu

6 Šo dokumentu nosaukumi atklāj diskutētās aktualitātes abu pušu starpā. Ziṇojumiem ir dažāâds raksturs un autoritātes abās baznīcās. 1972. gadā pieñemts Maltas ziṇojums Evangéelijs un Baznīca. Sekoja Laulības teologiija un dažādu konfesiju laulību problèma (1976), Eiharistija (1978), Ceļš uz kopību (1980), Garīgais amats Baznīcā (1981), Mārtinšs Luters - Jēzus Kristus liecinieks (1983), Sastopoties ar vienotību (1984), Baznīca un taisnošana: Baznīcas izpratne taisnošanas mācības gaismā (1993), Vienotā deklarācija par taisnošanu (1999), Baznīcas apustulicitāte (2006). Šo dokumentu uzskaitījums ir atrodams pēdējā kopīgā dokumenta publikācijas pielikumā: No konflikta uz kopību 2017, 92. Šo ziṇojumu pilnu tekstu, iznemot pēdējo, skat. četru sējumu izdevumā Meyer et al. 1983-2012.

7 Joint Declaration 1999. 
baznīcas kritiku. Savukārt katoḷi šādus atceres pasākumus uztvēra kā iespēju apsūdzēt luterānus par neattaisnojamu atdalī̌sanos no patiesās Baznīcas un Kristus evaṇgèlija noraidīšanu."» Tāpat tiek atgādināts, ka globalizācijas un pluralizācijas kontekstā konflikti konfesionālu iemeslu dēl samazina kristietības ticamību. ${ }^{9}$

Dokuments pievēršas arī jaunam vēstures interpretējumam. Tas atgādina, ka nozīmīgi ir koriḡèt atmiņas par vēsturi, to, kā tā tiek stāstîta tālāk, kā veidojas mūsu priekšstati par to, kas ir noticis. Šajā zinā konfesionālais skatījums ir jāpārskata un kritiski jāizvērtē. ${ }^{10}$

Jau 1983. gadā, atzīmējot M. Lutera 500 gadu jubileju, tika izdots dokuments Mārtinšs Luters - Jēzus Kristus liecinieks. Būtisks šajā dokumentā bija jaunais skatījums uz M. Lutera personību un paveikto. No katolı puses gadsimtiem ilgi skatījums uz M. Luteru izrietēja no aizsargpozīcijām, kamēr luterāṇi viņa personībā saredzēja ticības varoni, toties tagad, kā jau liecina pats dokumenta nosaukums, abas puses M. Lutera darbu vērtē no jauna. Viņš tiek atzīts par uzticamu kristietības liecinieku: "Kā teologs, sprediķotājs, dvēsel̦u kopējs, dziesmu rakstîtājs un lūdzējs Luters no jauna ir apliecinājis un licis atmirdzēt neparastā garīgā koncentrācijā bibliskajai vēstij par Dieva dāvājošo un atbrīvojošo taisnību."

Ziņojuma No konflikta uz kopību otrā nodaḷa turpina šo līniju, kas balstās uz 19. un 20. gs. vēsturiskajiem pētījumiem par reformāciju un M. Lutera personību. No skatījuma, kas saredzēja viņu kā ķeceri un baznīcas šķēlēju, subjektīvas uztveres absolutizētāju, katoḷu pētnieki nonāca pie atziņas par M. Luteru kā dziḷi reliǵiozu personību, kurš nostājās pret neīstu katolicismu un bija dedzīgs Dieva meklētājs. Katoḷu puse šajā laikā būtībā atklāja M. Luteru kā katoli, kā to, kurš vēlējās patiesu katolicismu: “.. Luters sevī uzveica

\footnotetext{
8 No konflikta uz kopību 2017, 5.

9 Turpat, 13-15.

10 Turpat, 18.

11 Als Theologe, Prediger, Seelsorger, Liederdichter und Beter hat Luther in ungewöhnlicher geistlicher Konzentration die biblische Botschaft von Gottes schenkender und befreiender Gerechtigkeit neu bezeugt und zum Leuchten gebracht. Martin Luther 1992, 450.
}

katolicismu, kas nebija pilnībā katolisks." ${ }^{12}$ Skatījums uz M. Lutera teoloǵiju ieguva citādu raksturu, sistemātiskā salīdzinājumā tika atklāts kopīgais viņa un Akvīnas Toma teologija $\bar{a}^{13}$ un saredzēts, ka daudzi M. Lutera uzskati jau bija raksturīgi katolicismam pirms viņa un/vai vēlāk ir tikuši integrēti katoḷu teolog̣ijā. ${ }^{14}$

Dokuments pievēršas arī luteriskās reformācijas vēstures norisēm (3. nodaḷā), atsakoties no nosodījuma, bet skaidrojot dažādo pušu viedoklus un par izteiksmes toni izvēloties nožêlu par notikumiem, kas nevis satuvināja, bet attālināja divas baznīcas puses. ${ }^{15}$

Tomēr dokumenta sirds ir atrodama nodaḷā par M. Lutera teologijijas pamattēmām luterāṇu un Romas katoḷu dialoga kontekstā. Te uzmanība ir koncentrēta uz četrām vina teolog̣ijas tēmām: taisnošana, Eiharistija, garīgais amats, kā arī Raksti un tradīija. Nodaḷa ietver M. Lutera mācības atspoguḷojumu, katoḷu teologiskās iebildes pret to, kā arī informāciju, kā šis jautājums ir ticis risināts ekumeniskajā dialogā. ${ }^{16}$

No visām četrām pieminētajām tēmām, šķiet, visaugstākā līmeņa konsenss ir atrodams teologiiskajā mācībā par taisnošanu. Te ziņojums No konflikta uz kopību atsaucas uz jau sasniegto vienprātību 1999. gada Vienotajā deklarācija par taisnošanas mācību. Atšksirības šajā jautājumā ir izskaidrojamas ar līdzīga satura formulējumu dažādos kontekstos, kas ir vedis pie pārpratumiem, un vienotība te lielā mērā ir panākama ar skaidrojumu. Piem.: "Kad luterāni pastāv uz to, ka cilvēks taisnošanu var vienīgi saṇemt, viṇi ar to domā: "Izslēgt jebkādu iespēju līdzdarboties savā taisnošanā, bet nenoliedz, ka ticīgie ir piln̄̄bā iesaistīti personīgajā ticībā, kuru ietekmē

12 No konflikta uz kopību 2017, 21.

13 Viens no galvenajiem veikumiem šajā laukā ir katolu teologa Oto Hermana Peša darbs, kurš Hamburgas Evaṇgēliskās teologiijas fakultātē darbojās kā sistemātiskās teoloǵijas profesors (1975-1998). Te pieminams vina darbs, kas salīizina taisnošanas teoloǵiju M. Lutera un Akvīnas Toma darbos: Pesch 1967.

14 No konflikta uz kopību 2017, 23.

15 Turpat, 35-90.

16 Turpat, 95. 
Dieva Vārds." (JDDJ 21)"17 Vai: "Kad katoḷi runā par sagatavošanos žēlastībai kā par "līdzdarbošanos", ar ko tiek domāta "cilvēka personīgā atḷauja”, kas pati par sevi "ir žēlastības rezultāts, nevis no cilvēka dabiskajām spējām radusies darbība" (JDDJ 20)"." Tādējādi viṇi neapstrīd kopīgo apgalvojumu, ka grēcinieki "paši saviem spēkiem nespēj griezties pie Dieva, lai meklētu pestīšanu, kā arī nespēj nopelnīt taisnošanu Dieva priekšā un paši nespēj iegūt pestīšanu. Taisnošana notiek vienīgi Dieva žēlastībā"'18 (JDDJ 19).

Arī attiecībā uz Svēto Vakarēdienu ekumeniskais dialogs ir sasniedzis tuvināšanos, skaidrojot abās tradīcijās lietotos jēdzienus, mēǵinot izskaidrot maizes un vīna elementu nozīmi. Konsenss ir sasniegts, vienojoties runāt par to, ka Jēzus Kristus "ir visā pilnībā klātesošs savā miesā un asinīs zem maizes un vīna zīmēm"'19. Taču jautājumi vairāk skar praktisku attieksmi, cik ilgi šì reālā klātbūtne elementos pastāv, kā būtu jāizturas pret Vakarēdiena elementiem pēc dievkalpojuma, vai laji bauda Vakarēdienu zem vienas vai divām zīmēm. Par spīti atvērtībai kopīgas teoloǵiskas izpratnes veidošanā attiecībā uz eiharistiju, tomēr neuzdots paliek jautājums par kopīgu eiharistijas iestādīšanu un baudīšanu. ${ }^{20}$

Šis jautājums ir cieši saistīts ar nākamo, proti, ar izpratni par garīgo amatu. Šajā jautājumā, lai arī dokuments No konflikta uz kopību meklē saskarsmes punktus un arī atrod,

17 No konflikta uz kopību 2017, 127. JDDJ - Joint Declaration on the Doctrine of Justification Vienotā deklarācija par taisnošanas mācību.

18 No konflikta uz kopību 2017, 128.

19 Turpat, 154.

${ }^{20}$ Lai arī daudzkārt praksē dažādu konfesiju piedalī̌sanās Vakarēdiena svinībās notiek, tomēr vēl joprojām oficiāāā līmenī šis jautājums netiek atrisināts. Šajā zin̄ā Romas katoḷu kanoniskās tiesības nosaka: "Katoḷ kalpotāji iestāda sakramentus tikai katolu ticīgajiem, tāpat tiem ir lauts saṇemt tos tikai no katoḷu kalpotājiem ..." Izṇēmums ir apdraudējuma situācijas, ja tajās katoḷu kalpotājs nav pieejams. Skat. Code of Canon Law $844 \S 1,2,3,4$. Šis noteikums, protams, ir īpaši sāpīgs, piem., laulībās, kurās partneri pieder pie dažādām konfesijām. Vēl nesen arī priesteri ir tikuši disciplinēti, jo piedalījušies ekumeniskā eiharistijā. Sal. Die deutschen Bischöfe 2003. tomēr atšķirības izpratnē par garīgo amatu un tā leǵitimitāti ir būtiskas. Kopīgais saskares punkts abu baznīcu starpā ir atzina par vispārējo, t. i., visu kristīto, priesterību. Ikvienam ticīgajam ir savs uzdevums sludināt un tā piedalīties kopīgā Kristus miesas misijā. ${ }^{21}$ Tomēr būtiskas atškirirības pastāv ordinētā kalpošanas amata lomas izpratnē, īpaši bīskapa amata nozīmes nodrošināšanā baznīcas identitātē un vienotībā. Saskaņā ar katoḷu mācību bīskaps pastāv apustuliskajā pēctecībā, t. i., ar to, ka viṇš ir kopībā ar visu bīskapu kārtu, kas kopīgi manto apustulu misiju. Šì kopība no katoḷu puses luterāņiem tiek apstrīdēta. "Katoḷi uzskata, ka luterāṇu ordinācijai trūkst sakramentālās zīmes pilnības. Katoḷu mācībā apustuliskās pēctecības prakse un mācība bīskapa amatā, kas reizē ar trīsdalīgo [svētdarīšanas, mācīšanas un valdīšanas - aut. piez.] amatu ir dala no pilnīgas Baznīcas struktūras. Šì pēctecība izpaužas kolektīvā veidā - bīskapi tiek uznemti katoḷu bīskapu kolēgijā un tādējādi ir pilnvaroti ordinēt. Tāpēc katoḷu doktrīna māca, ka luterānuu baznīcās ordinācijas svêtā zīme nav pilnībā klātesoša, jo tie, kas ordinē mācītājus, nedarbojas šajā kopībā." 22 Tātad luterāṇu priesterība netiek pilnībā atzīta. Turklāt Romas pāvestam katoḷu baznīcā tiek piedēvēta piln̄̄ga, augstāka un universāla vara pār baznīcu, savukārt bīskapu kolēǵija "veic augstāko un pilnīgu varu pār universālo baznīcu kopā ar tās galvu, Romas pāvestu, un nekad bez galvas". ${ }^{23}$

Attiecībā uz Rakstu autoritāti un baznīcas amata autoritāti M. Luters uzsvēra principu sola scriptura, tādējādi ierādot augstāko autoritāti baznīcā Rakstiem, kam pakḷauti baznīcas amati un kas izškir teologiskos strīdus. Katoḷu baznīcas uzskati atškiras no M. Lutera laika uzskatiem. Lai arī Vatikāna II koncils runā par to, ka Baznīcai pieder "galējais spriedums", taču ar to netiek domāts, ka tikai maǵistērijs ekskluzīvi ir tiesīgs skaidrot Rakstus. Te būtībā ir panākta vienotība abu baznīcu uzskatos. ${ }^{24}$

Izvērtējot radušos dokumentu, jāatzīst, ka vislielākais ieguvums abu baznīcu dialoga un dokumenta veidošanā ir formulētais

\footnotetext{
21 No konflikta uz kopību 2017, 177.

22 Turpat, 191.

23 Turpat, 192.

24 Turpat, 209-210.
} 
ekumeniskais nolūks, ko tā autori noslēgumā ir iekḹāvuši kā vienu no ekumeniskajiem imperatīviem, proti: "katoḷiem un luterāņiem vienmēr ir jāstiprina kopīgais un vispirms jāskatās no vienotības, nevis sašķeltības skatpunkta, pat ja atšksirības var vieglāk pamanīt un piedzīvot". ${ }^{25}$ Šis nolūks patiešām ir manāms izstrādātajā dokumentā, un tādējādi tas var būt par paraugu ekumeniska dialoga veidošanai un attīstīšanai. Atbildībā pret abām tradīcijām un sasniegtā vienprātības līmeņa dẹl vislielākā kḷūda būtu ieslīgt vienkāršotā pretējās puses teologijas kritikā, tādā veidā mēǵinot atgādināt par atšķirībām, kurās vēl nav ne tuvu sasniegta vienprātība un vēl mazāk kopība. Šis dokuments ir labs pamats jaunai pieejai arī atšķirību diskutēšanai.

Taču nevar nepieminēt vienu no sāpīgajiem jautājumiem katoḷu un luterāņu starpā, kam šis dokuments tomēr pievērš pārāk maz uzmanības ${ }^{26}$, un tas ir jautājums par baznīcas izpratni, identitāti, par to, vai tās spēj arī dažādībā pilnībā atzīt viena otras pilnvērtīgu baznīciskumu. Tieši tajā, kā jau minēts šī raksta sākumā, pastāv patiesa ekumene, pat ne vienotu uzskatu izveidošanā dažādos teologisku uzskatu jautājumos. Kā liecina arī šis dokuments, viens no galvenajiem jautājumiem te ir baznīcas amata izpratne, un var vienīgi cerēt, ka dialoga turpinājums samazinās teritoriālās cīṇas, kas traucē šim ekumenes mērķim, - arī atškkirībās atzīt otru tradīciju. Katrā ziṇā, lai ekumeniskais dialogs nepārvērstos par laiku tērējošu small talk, šie jautājumi paliek darba kārtībā.

Atgriežoties vēlreiz pie š̄ raksta sākumā uzdotā jautājuma, vai ir iespējamas ekumeniskas reformācijas svinības, jāatzīst, ka ekumeniskā redzējumā reformācijas vēsturē ir atrodamas lappuses, kurām jāved mūsdienu baznīcas pie nožēlas, gan arī lappuses, kas ekumenei ir patiešām nozīmīgas. Kā raksta luterāṇu teologs Volfārts Pannenbergs: "Baznīcas sašḳelšanās 16 . gs. nevar tikt saredzēta kā

${ }^{25}$ No konflikta uz kopību 2017, 239.

26 Šim jautājumam kā garāmejot pievērsta uzmanība vien trijos dokumenta punktos: No konflikta uz kopību 2017, 213-215. reformācijas panākums, bet var tikt saprasta tikai kā tās pagaidu zaudējums, jo reformācijas mērḳis taču bija visas baznīcas atjaunošanās uz tās bibliskā pamata." ${ }^{27}$ Tomēr abu baznīcu starpā ir atrodamas kopīgas teologiskas nostādnes, kas reformācijā iemirdzējās ar jaunu spēku. Viena no tām ir pārliecība par taisnošanu ticībā, kas vieno abas teologíiskās tradīcijas.

Arī Latvijā dokumenta No konflikta uz kopību publikācijas atvēršana norisinājās ekumeniskā gaisotnē Latvijas Evangéēliski luteriskās baznīcas Virsvaldē 2018. gada 11. janvārī. Šì dokumenta veidošanā piedalījās arī latviešu teolog̉e, tagad ordinēta mācītāja Vācu evangóēliski luteriskajā baznīcā Sandra Gintere. Neapšaubāmi, Latvijā norisinās ekumeniskas lūgšanas un dievkalpojumi, dažkārt pat tiek aizgūtas noteiktas prakses vai teoloǵiski uzskati, tomēr tālākam ekumenes ceḷam būtu vēlams padziļināt teologisko dialogu dažādu tradīciju starpā. Šādu dialogu būtu nepieciešams veidot uz akadēmiskās teoloǵijas bāzes. Tās nozīmību parāda jau līdzšinējais ekumeniskais dialogs, kurā jauna pieeja, jauns skatījums uz vēsturi bija iespējams, pateicoties akadēmiskiem pētījumiem, kas deva iespēju kritiski izvērtēt konfesionālos aizspriedumus, kā arī ekumeniskā perspektīvā argumentēti skaidrot teoloǵiskos konceptus. Vispirmām kārtām Latvijā šāds teoloǵiskais darbs būtu nepieciešams, lai stiprinātu konfesionālo identitāti un pašcien,u, uz kuru pamata veidot cienpilnas un līdzvērtīgas attiecības arī ar citu tradīciju pārstāvjiem. Tas būtu nepieciešams, arī meklējot dialogu ar savas konfesijas baznīcām, vismaz luteriskās baznīcas gadījumā. Dokuments No konflikta uz kopību ir labs atgādinājums arī Latvijas kristietībai, ka neviena baznīca šajā pasaulē nevar uzvesties tā, ka tā būtu vienīgā vai vismaz vienīgā pareizā, mūsdienu pluralitātes un globalizācijas laikmetā arī skatījums uz savu tradīciju ir iespējams, tikai rēķinoties ar ekumeni.

27 Die Spaltung der Kirche im 16. Jahrhundert kann ja nicht als Erfolg der Reformation, sondern kann nur als Ausdruck ihres vorläufigen Scheiterns verstanden werden; zielte die Reformation doch auf eine Erneuerung der ganzen Kirche aus ihrem biblischen Ursprung. Pannenberg 1979, 113. 


\section{VĒRES}

Code of Canon Law 844. Pieejams: http://www.vatican.va/archive/ENG1104/_P2T.HTM (05.07.2018.).

Dekret Unitatis redintegratio über den Ökumenismus (21.11.1964.) Pieejams: http://www.vatican.va/archive/hist_councils/ii_vatican_council/documents/vat-ii_decree_19641121_unitatis-redintegratio_ge.html (04.05.2018.).

Die deutschen Bischöfe sind römischer als Rom (06.06.2003.) Spiegel Online. Pieejams: http://www.spiegel.de/panorama/abendmahlsstreit-die-deutschen-bischoefe-sind-roemischer-als-rom-a-251848.html (17.07.2018.).

Joint Declaration on the Doctrine of Justification by the Luther an World Federation and the Catholic Church (1999) Pieejams: https://www.lutheranworld.org/sites/default/files/Joint\%20Declaration\%20 on\%20the\%20Doctrine\%20of\%20Justification.pdf (02.04.2018.).

Körtner, U. (2007) Differenzökumene und Ökumene der Profile: Kirchliche Identitäten im Wandel. Deutsches Pfarrerblatt, 9, 480-482.

Martin Luther - Zeuge Jesu Christi (1992) Meyer, H.; Papandreou, D.; Urban, H. J.; Vischer, L. (Hrsg.). Dokumente wachsender Übereinstimmung. Paderborn : Bonifatius/Frankfurt a. M. : Lembeck.

Meyer, M. (2015) Zur Geschichte der ökumenischen Bewegung. Konfessionskundliches Institut Bensheim (18.02.2015.). Pieejams: http://konfessionskundliches-institut.com/essay/zur-geschichte-der-oekumenischen-bewegung-2/(04.05.2018.).

Meyer, H.; Papandreou, D.; Urban, H. J.; Vischer, L. (Hrsg.) (1983-2012) Dokumente wachsender Übereinstimmung. Paderborn : Bonifatius/Frankfurt a. M. : Lembeck.

No konflikta uz kopību: Luterāņu un katoļu kopīga reformācijas gadadienas atcere 2017. gadā (2017) Rīga : Latvijas Evaņgèeliski luteriskā baznīca.

Pannenberg, W. (1979) Die Augsburger Konfession und die Einheit der Kirche. Ökumenische Rundschau, 28.

Pesch, O. H. (1967) Theologie der Rechtfertigung bei Martin Luther und Thomas von Aquin: Versuch eines systematisch-theologischen Dialogs. Mainz : Matthias Grünewald. 